\title{
Data on zooplankton occurrence and abundance in the Far East seas and adjacent Pacific Ocean waters
}

\author{
Igor V. Volvenko
}

Pacific Branch of Russian Federal Research Institute of Fisheries and Oceanography (TINRO), 4 Shevchenko Ave., 5 Vladivostok, 690091, Russia, E-mail: oknevlov@gmail.com, ORCiD id: 0000-0003-0369-4039

Abstract. The article describes a unique dataset of zooplankton collected by the large Juday net in the North Pacific - one of the most productive and economically important regions of the world ocean (Volvenko, 2021a https://doi.pangaea.de/10.1594/PANGAEA.937751): the sources and extent of the information contained therein, its benefits and drawbacks, the first operating experience and prospects. The information in this dataset has already been used to quantify

10 the inventory of marine biological resources and appraise the waters of the Far East seas and adjacent Pacific Ocean. In 2016, five tabular reference books were created and printed containing the species composition, occurrence (samples, \%) and abundance (ind. $/ \mathrm{m}^{3}, \mathrm{mg} / \mathrm{m}^{3}$ ) of zooplankton in the surveyed area. The data is aggregated by species, developmental stages, size fractions, standard regions, vertical layers of water, light and dark time of day, four seasons of the year and multi-year periods. This information has recently been verified, corrected, translated into English and from text to digital format, and

15 supplemented by GIS with maps of the standard regions by which data was summarized with their morphometric characteristics (Volvenko, 2021b https://doi.pangaea.de/10.1594/PANGAEA.937752) to increase its availability to the scientific community worldwide. The scope of application of this data is fundamental to the management of marine resources, aquaculture development, nature conservation, and assessment of the damage of various anthropogenic factors on nature.

Keywords: assessment of waters; database; long-term monitoring; North Pacific; tabular reference books; zooplankton

\section{Introduction}

Since the end of the 1970s the Pacific Branch of Russian Federal Research Institute of Fisheries and Oceanography (TINRO) has adhered to the ecosystem approach to the study and management of living aquatic resources, which involves the collation and analysis of data for all groups of animals, highlights the interconnections between them and the role of the climate and hydrological regime in the fluctuations of their numbers (May, 1984; Shuntov, 1988, 1995, 2004, 2010; Shuntov et al., 1997;

25 Lapko, 2000; Bocharov, Shuntov, 2003; Dulepova, 2005; Misund, Skjoldal, 2005; Bianchi, Skjoldan, 2008; Beamish, Rothschild, 2009; Bulatov, Kotyenyov, 2012; Shuntov, Temnykh, 2013). In large-scale integrated marine expeditions, all sorts of information about marine biological communities and their abiotic environment have been collated via this approach over the last 45 years in the North Pacific and adjacent Arctic. Nekton, benthos and nektobenthos are counted primarily by the 
https://doi.org/10.5194/essd-2021-415

Preprint. Discussion started: 3 December 2021

(c) Author(s) 2021. CC BY 4.0 License.

(c) (i)

trawling method, and each trawl is accompanied by the collation of oceanographic data. Since 1984 up to now, plankton

samples have been taken at all measurement stations according to a common standard.

Mesofauna, the details of which are aggregated in the new dataset described here, is caught by the plankton net. These organisms have a small body size and weight from hundreds to thousandths of a milligram, and are primarily the food supply for trawl macrofauna, marine birds and mammals, and also the larvae of invertebrates and fish, the so-called net zooplankton ${ }^{1}$.

This dataset contains information on the status and spatial-temporal dynamics of the planktonic part of the highly productive ecosystems (which provides 90\% of the total Russian catch of fish and other marine organisms (Bocharov, 2004, 2010) during a time period in which there were considerable transformations in the biota of the region caused by changes to global climate and oceanological and cosmic-geophysical factors (e.g.: Shuntov et al., 1993, 1997, 2007; Shuntov, 1994, 1998; Shuntov, Temnykh, 2011). Therefore, it is difficult to overestimate its role in the ecosystem, biogeographic, trophological and bioresource studies of the Far Eastern seas of Russia and adjacent waters of the Pacific Ocean.

The article provides a detailed description of how this unique dataset was created, the sources and volume of information contained in it, its benefits and drawbacks, some results achieved through it concerning the quantitative inventory of marine biological resources and appraisal of waters in the North Pacific, the future prospects for its utilization in applied and fundamental research

\section{Materials and Methods}

45 Plankton were collected using a large standard sized Juday net made of kapron sieve No. 49 (0.168 mm mesh) with a $0.1 \mathrm{~m} 2$ opening (Fig. 1) from a depth of $200 \mathrm{~m}$ to the surface, and where the depth is less than $200 \mathrm{~m}$ from the bottom to the surface. To study the upper pelagic water layer additional plankton samples were collected in the standard layer 0-50 m. Other depths are sampled layer-by-layer to study the migration and of vertical distribution plankton. Samples processed by the express method (Volkov, 1984, 1996a, 2008a) with the separate analysis of three size fractions - length of 0.6-1.2 mm (fine/small),

50 1.2-3.2 mm (medium) and > $3.2 \mathrm{~mm}$ (large). Research groups usually work in two shifts, so the data collection takes place both day and night in order to calculate the vertical diurnal migration of euphausiids, copepods and hyperiids, which descend during the day into the deeper layers beyond the epipelagic zone. Surveys are performed all year round, if possible, and annually across standard sampling grid. They regularly cover the entire exclusive economic zone of Russia and sometimes the adjacent waters (Volvenko, 2015a).

Other features of the collection, processing and storage of data are described in Supplement 1.

\section{Results}

During the implementation of the Concept of Information Support for fundamental and applied research (Volvenko, 2015a, 2016) a zooplankton DB was created (see Supplement 1 for details). Based on the DB, in 2015 five tabular reference books

\footnotetext{
${ }^{1}$ Hereinafter referred to as zooplankton for short without specifying that it is net zooplankton and without the prefix meso.
} 
https://doi.org/10.5194/essd-2021-415

Preprint. Discussion started: 3 December 2021

(c) Author(s) 2021. CC BY 4.0 License.

(c) (i)

(Dolganova, Volvenko, 2016a, b; Volkov, Volvenko, 2016a-c) of the species composition and abundance of zooplankton in a major fishing region of Russia (Fig. S3) were prepared and submitted for publication. Three of them are devoted to the Far Eastern seas: the western part of the Bering Sea, the north-west of the Sea of Japan and the Sea of Okhotsk; one - the northwestern part of the Pacific Ocean. The increased density of the measurements is clearly visible in these areas (Fig. 1), as they were taken in an area, which is constantly monitored by the TINRO, and studied much better than others. A separate volume is devoted to the Peter the Great Bay in the Sea of Japan. This bay has unique fauna, its coast contains much of the populace and industry of the Russian Far East, it has a highly promising aquaculture industry, and unlike most other areas of the Far Eastern seas, only the plankton in the neritic zone has been adequately studied here. The new tabular reference books contain a total of nearly five thousand pages.

The tables contain information on the occurrence (number of samples in which this species/group of animals was found, and their share in percentage terms of the total number of measurements), the average abundance (specimens $/ \mathrm{m}^{3} \mathrm{and} \mathrm{mg} / \mathrm{m}^{3}$ ) and the standard error of mean with the Sheppard's correction. The species and other taxonomic groups of marine organisms are not sorted systematically but in alphabetical order, and then in ascending order of size by fraction, developmental stage and/or size. The final rows of the tables - "Entire zooplankton”, “Meroplankton”, “Amphipods”, “Copepods”, “Euphausiids” etc. (see left column in Table S3) contain the corresponding total group means and standard errors calculated by the formula $m_{\sum x}=\sqrt{m_{1}^{2}+m_{2}^{2}+\ldots+m_{n}^{2}}$, where $m_{\sum x}$ is the sampling error of the sum $n$ of the arithmetic means, following their 75 errors $m_{1}-m_{n}$.

Examples of five tables from (Volkov, Volvenko, 2016a) are given in the Supplement 2 to this article. They contain long-term average data about the plankton of regions No 1-5 (see Fig. 1) of the Bering Sea.

In general the format of these tables is the same as in the previously published reference books on nekton published in 2003-2006 (Shuntov, Bocharov, 2003b, 2004b, 2005b, 2006b) as tabular annexes to nekton atlases (Shuntov, Bocharov, 2003a, 80 2004a, 2005a, 2006a), tabular reference books on the pelagic trawl macrofauna published in 2012 (Shuntov, Bocharov, 2012ac), and benthic macrofauna published in 2014 (Shuntov, Bocharov, 2014a-e). Information in them is also grouped by: 56 standard biostatistical areas (see 48 light unshaded areas on the bottom map Fig. 1, and 8 areas in the insert in its middle left corner), which are natural systems characterized by relatively uniform waters according to the formation of their properties in specific local geographical, geomorphological, climatic and hydrological conditions. There is now a certain standard for georeferencing spatially distributed information, ensuring the comparability of diverse environmental information and the continuity of the long-term monitoring data on the state of the waters (Volvenko, 2003d).

Besides the described zoning, the reference books contain four principles relating to grouping and the selection of raw data:

1) By sampled water layer, measurements are divided into:

epipelagic - final catch depth $0 \mathrm{~m}$, initial 100-200 $\mathrm{m}$ (or the bottom, if depth is $\leq 300 \mathrm{~m}$ ), 
upper epipelagic - final catch depth $0 \mathrm{~m}$, initial 25-50 $\mathrm{m}$ (or bottom, if depth is $\leq 70 \mathrm{~m}$ ).

2) By time of day they are divided into:

day - obtained during daylight,

night - obtained in the dark or at dusk.

95 3) Seasonally (in this case, this means not the calendar but the biological seasons, the measurements are divided into made:

from June 1 to September 15 - summer,

from September 16 to November 30 - autumn,

from December 1 to March 31 - winter,

from 1 April to 31 May - spring.

100 4) There are 4 multi-year periods:

1984-1990 - 'Sardine and pollock fish abundance',

1991-1995 - 'Transitional period of sharp decline in abundance',

1996-2005 - 'Period of low-level new fish productivity growth',

2006-2013 - 'Salmon period'.

105 These principles of grouping, selection and averaging data are implemented in the majority of the TINRO ecological studies (e.g.: Shuntov, Bocharov, 2003a-b, 2004a-b, 2005a-b, 2006a-b, 2012a-c, 2014a-e; Volvenko, 2003a-c, 2004a-c, 2005a, b, 2007, 2016; Shuntov et al., 2007; Shuntov, Temnykh, 2008; Volkov, 2014 and many others).

\section{Discussion}

The data in these tables enable evaluation of the total stock plankton biological resources of the Far Eastern seas of the North

110 Pacific. With the use of the so-called volume method, the absolute abundance of marine organisms is calculated by multiplying their average density (specimens $/ \mathrm{m}^{3}$ or $\mathrm{mg} / \mathrm{m}^{3}$ ) by the corresponding volume of water (thousand $\mathrm{km}^{3}$ ). The result gives, respectively, trillions of specimens and thousands of tons. For this, the standard morphometric characteristics of the areas listed in each of the aforementioned tabular reference books should be used. For convenience, they are all placed in dbf files of maps in Volvenko (2021b). (Note that many opponents of applying corrections to catch efficiency can easily recalculate the data published in books in their own way, by divide any of the density parameters - abundance or biomass - by the correction factor given in each row. Those who wish to use different correction factors can also easily recalculate the density by dividing it by our correction and then multiplying it by their own).

With these same tables it is easy to recalculate the volumetric characteristics of density into areal characteristics. To do this, multiply the average abundance or biomass by volume of water corresponding to the water area, and then divide it by its area. The result will be in the billions of specimens $/ \mathrm{km}^{2}$ or $\mathrm{t} / \mathrm{km}^{2}$. From the tables it is easy to calculate the plankton content in the middle and lower epipelagic, i.e. from 50-200 m (based on the difference of concentrations from 0-200 m and 0-50 m) and the average individual weight of animals (by dividing their biomass by number), and using previously published tables on calorific value and the chemical composition of zooplankton (e.g. Borisov et al., 2004), you can obtain its energy 
characteristics, etc.

In this way a significant contribution to the new quantitative inventory of aquatic biological resources and appraisal of the waters of the North Pacific has been made. A series of these monographs is recommended not only to planktonologists, but also to ecologists, biogeographers, hydrobiologists, ichthyologists, teachers and students of related disciplines. In the scope of their application is the management of living aquatic resources, aquaculture development, and nature conservation, because they can be used to assess the effects of various anthropogenic factors on nature (pollution, the construction of hydraulic structures, oil and gas extractions, tanker accidents, nuclear reactors, etc. $)^{2}$.

The free wide international use of the data published in the five reference books has so far been hampered by three circumstances. 1) They are published in Russian and not translated into English. 2) They are published in text (pdf) format and not digitized. 3) The data collectors used outdated species identification guides, so there are many outdated species names in the tables (Table S4).

To eliminate these shortcomings, I:

- wrote this article detailing the origin of the data and methods of its processing;

- $\quad$ digitized the data of reference tables from five books (Fig. S3) and saved them in xlsx and csv formats;

- translated the Russian text into English;

- fixed species names to modern;

- summed up the characteristics of abundance where synonyms were considered as different species;

- prepared a shape-file with polygons of the standard regions (Fig. 1) by which data is summarized;

- accompanied the polygons with information about coordinates, surface areas and water volumes in each of them.

\section{Data availability}

Full dataset provided in xlsx and csv files (Volvenko, 2021a https://doi.pangaea.de/10.1594/PANGAEA.937751) as well as

145 maps of regions with their morphometric characteristics in shapefiles (Volvenko, 2021b https://doi.pangaea.de/10.1594/PANGAEA.937752). For purchase hard copy of reference books (their electronic versions are freely available now at the links in the list of references) one should contact the Directorate of the Pacific Branch of Russian Federal Research Institute of Fisheries and Oceanography (TINRO) E-mail: tinro@tinro-center.ru, contact information on the site: http://www.tinro.vniro.ru/en/contacs; or Directorate of the Russian Federal Research Institute of Fisheries and Oceanography (VNIRO) E-mail: vniro@vniro.ru, contact information on the site: http://vniro.ru/en/about-vniro/contacts

\footnotetext{
${ }^{2}$ However, in the process of testing the DBs, when creating the tabular reference books some irremovable shortcomings were found (see Supplement 1). This is common to most modern zooplankton datasets.
} 
https://doi.org/10.5194/essd-2021-415

Preprint. Discussion started: 3 December 2021

(c) Author(s) 2021. CC BY 4.0 License.

(c) (i)

\section{Conclusions}

According to the reputable expert opinions, the dataset described above is stronger than many of the widely spatially covered zooplankton datasets available. Despite the shortcomings noted in Supplement 1 , the substantial volume and high quality of the collated data gives hope that the information presented in the five reference books and these dataset together with previously published data on pelagic and benthic macrofauna and data on the nutrition of common fish and squid, which is now being compiled in the TINRO laboratories, will enable the next important steps to be taken in the understanding of the nature of the Far Eastern seas and the Pacific.

\section{References}

Baranov, F.I. 1933. Commercial fishing techniques. Kogiz, Moscow, Leningrad. (In Russian).

Beamish, R.J. and Rothschild, B.J., ed., 2009. The Future of Fisheries Science in North America. Springer Science + Business Media, Dordrecht.

Bianchi, G., Skjoldan, H.R. 2008. The Ecosystem Approach to Fisheries. Food and Agriculture Organization of the United Nations, Wallingford, UK; Cambridge, MA; CABI; Rome.

Bocharov, L.N. 2004. The Perspective Approach to the Problem of People Supply with Fishery Products. Izvestiya TINRO, 138, 3-18. (In Russian).

Bocharov, L.N. 2010. Development of Fishery Science in the Far East. Tasks and Peculiarities of the Present-Day Stage. In TINRO-85, Results of the Decade. 2000-2010. TINRO-Center, Vladivostok, pp. 3-24. (In Russian).

Bocharov, L.N., Shuntov, V.P. 2003. State and Tasks of the Present-Day Stage of Ecosystem Researches of Biological Resources of the Far Eastern Seas of Russia. In: Rational Environmental Management and Management of Marine Bioresources: Ecosystem Approach. TINRO-Center, Vladivostok, pp. 3-8. (In Russian).

Borisov, B.M., Volkov, A.F., Gorbatenko, K.M., Koval, M.V., Shershneva, V.I. 2004. Standard tables of the wet weight and some biochemical parameters (calorie content, fats, proteins, carbohydrates, and the mineral rest) of zooplankton in the Far East Seas. Izvestiya TINRO, 138, 355-367. (In Russian).

Bulatov, O.A., Kotyenyov, B.N. 2012. Prospects of the Ecosystem Management of Fishery. In: Proceedings of All-Russia Scientific Conference Sustainable Use of Biological Resources of the Seas of Russia: Problems and Prospects. VNIRO, Moscow, pp. 10-11. (In Russian).

Clutter, R.I., Anraku, M. 1968. Avoidance of samplers in zooplankton sampling. In: UNESCO monographs on oceanographic methodology. No. 2: Zooplankton sampling. UNESCO Press, Paris, pp. 57-76.

Codifier of zooplankton species. 1980. VNIRO, Moscow, PINRO. (In Russian).

Dolganova, N.T., Volvenko, I.V.. 2016a. Net Zooplankton of the Northwestern Part of Japan (East) Sea: Occurrence, Abundance, and Biomass. 1985-2013. TINRO-Center, Vladivostok. https://www.researchgate.net/publication/329076424_Net_zooplankton_of_the_northwestern_part_of_Japan_East_ 
https://doi.org/10.5194/essd-2021-415

Preprint. Discussion started: 3 December 2021

(c) Author(s) 2021. CC BY 4.0 License.

(c) (i)

sea_occurrence_abundance_and_biomass_1985-2013 (In Russian).

Dolganova, N.T., Volvenko, I.V. 2016b. Net Zooplankton of Peter the Great Bay (Japan/East Sea): Occurrence,

Abundance, and Biomass. 1988-2013. TINRO-Center, Vladivostok.

https://www.researchgate.net/publication/329076283_Net_zooplankton_of_Peter_the_Great_Bay_JapanEast_Sea_0 ccurrence_abundance and biomass_1988-2013 (In Russian).

Dulepova, E.P. 2005. Ecosystem Researches of TINRO-Center in the Far Eastern Seas. Izvestiya TINRO, 141, 3-29. (In Russian).

Dulepova, E.P. 2014. Dynamics of production parameters for zooplankton as the main component of forage base for nekton in the western Bering Sea. Izvestiya TINRO, 179, 236-249. (In Russian).

Fisheries commercial and biological data unified registration forms (completion and perforation instructions). 1976. VNIRO, Moscow. (In Russian).

Gorbatenko, K.M., Dolganova, N.T. 2006. Compared catch efficiency of different types of plankton nets in the Far East Seas. Izvestiya TINRO, 146, 213-225. (In Russian).

Gorbatenko, K.M., Dolganova, N.T. 2007. Comparing the catch efficiency with different types of plankton nets in the high production zones of the Pacific Ocean. Oceanology, 47, 205-212. (In Russian).

Grese, V.N., Balandina, E.P., Bileva, O.K., Makarova, N.P. 1975. Efficiency of devices for the collection of plankton and its real density. Hydrobiologicheskyi Jurnal (Kiev), 11, 108-111. (In Russian).

Instructions for completing the unified commercial and biological data registration forms. 1982. VNIRO, Moscow. (In Russian).

Kiselev, I.A.. 1969. Plankton of seas and continental water bodies. V. 1. Leningrad: Nauka. (In Russian).

Kulikov, A.S. 1993. Zooplankton of the Bering Sea and its role in the functioning of plankton community. D. Ph. thesis. IGCE, Moscow. (In Russian).

205 Kun, M.S. 1975. Zooplankton of the Far Eastern seas. Pischevaya promyshlennost, Moscow. (In Russian).

Lapko, V.V. 2000. Ecosystem Studies of Biological Resources in TINRO-Center. In: TINRO-75 Years (from TONS to TINRO-Center). TINRO, Vladivostok, pp. 146-154. (In Russian).

May, R.M., ed. 1984. Exploitation of marine communities. Springer-Verlag, Berlin ets.

Mikulich, L.V., Rodionov, N.A. 1975. Weight Characteristics of Some Zooplankters of the Sea of Japan. Hydrobiological Investigations in the Sea of Japan and in the Pacific Ocean. In: Trudy Tikhookeanskogo Okeanologicheskogo Instituta. V. 9. DVNTs AN SSSR, Vladivostok, pp. 75-87. (In Russian).

Misund, O.A., Skjoldal, H.R. 2005. Implementing the ecosystem approach: experiences from the North Sea, ICES, and the Institute of Marine Research, Norway. Marine Ecology Progress Series, 300, 260-265.

Musaeva, E.I., Nezlin, N.P. 1996. Comparison of various zooplankton sampling tools based on catches in the Bering Sea. Oceanology, 35, 857-861. (In Russian).

Shuntov, V.P. 1988. Biological Resources of Far Eastern Seas: Prospects of Research and Exploitation. Biologiya Morya 
https://doi.org/10.5194/essd-2021-415

Preprint. Discussion started: 3 December 2021

(c) Author(s) 2021. CC BY 4.0 License.

(c) (i)

(Marine Biology), 3, 3-14. (In Russian).

Shuntov, V.P. 1994. New Data on Alterations in Pelagic Ecosystems of Far Eastern Seas. Vestnik DVO RAN, 2, 59-66. (In Russian).

Shuntov, V.P. 1995. TINRO’s Ecosystem Studies of the Far Eastern Seas Biological Resources. In: TINRO-70 (Vladivostok: TINRO). TINRO, Vladivostok, pp. 20-31. (In Russian).

Shuntov, V.P. 1998. Reorganizations in the Okhotsk sea pelagic ecosystems - real fact. Rybnoye Khozyaistvo (Fisheries), 1, 25-27. (In Russian).

Shuntov, V.P. 2001. Biology of the Far Eastern Seas of Russia. V. 1. TINRO-Center, Vladivostok. (In Russian).

Shuntov, V.P. (Ed.) 2004. Reports of the International Conference "Environmental Management and Management of Marine Bioresources: Ecosystem Approach”. Izvestiya TINRO, 137. (In Russian).

Shuntov, V.P. 2010. Some results of ecosystem studies of biological resources of the Far Eastern seas in connection with problems for further research. In: Bulletin $N 5$ implementation of "Concept of the Far Eastern basin program of Pacific salmon study". TINRO-Center, Vladivostok, pp. 186-195. (In Russian).

Shuntov, V.P, Bocharov, L.N., ed. 2003a. Atlas of Quantitative Distribution of Nekton Species in the Okhotsk Sea. National Fish Resources, Moscow. (In Russian).

Shuntov, V.P., Bocharov, L.N., ed. 2003b. Nekton of the Okhotsk Sea. Tables of Abundance, Biomass and Species Ratio. TINRO-Center, Vladivostok. (In Russian).

Shuntov, V.P., Bocharov, L.N., ed. 2004a. Atlas of Quantitative Distribution of Nekton Species in the Northwestern Part of the Japan/East Sea. National Fish Resources, Moscow. (In Russian).

Shuntov, V.P., Bocharov, L.N., ed. 2004b. Nekton of the Northwestern Part of the Japan/East Sea. Tables of Abundance, Biomass and Species Ratio. TINRO-Center, Vladivostok. (In Russian).

Shuntov, V.P., Bocharov, L.N., ed. 2005a. Atlas of Quantitative Distribution of Nekton Species in the Northwestern Part of the Pacific Ocean. National Fish Resources, Moscow. (In Russian).

Shuntov, V.P., Bocharov, L.N., ed. 2005b. Nekton of the Northwestern Part of the Pacific Ocean. Tables of Abundance, Biomass and Species Ratio. TINRO-Center, Vladivostok. (In Russian).

Shuntov, V.P., Bocharov, L.N., ed. 2006a. Atlas of Quantitative Distribution of Nekton Species in the Western Part of the Bering Sea. National Fish Resources, Moscow. (In Russian).

Shuntov, V.P., Bocharov, L.N., ed. 2006b. Nekton of the Western Part of the Bering Sea. Tables of Abundance, Biomass and Species Ratio. TINRO-Center, Vladivostok. (In Russian).

Shuntov, V.P., Bocharov, L.N., ed. 2012a. Pelagic Macrofauna of the Western Part of the Bering Sea: Tables of Occurrence, Abundance and Biomass. 1982-2009. TINRO-Center, Vladivostok. (In Russian).

Shuntov, V.P., Bocharov, L.N., ed. 2012b. Pelagic Macrofauna of the Okhotsk Sea: Tables of Occurrence, Abundance and Biomass. 1984-2009. TINRO-Center, Vladivostok. (In Russian).

250 Shuntov, V.P., Bocharov, L.N., ed. 2012c. Pelagic Macrofauna of the Northwestern Part of the Pacific Ocean: Tables of 
https://doi.org/10.5194/essd-2021-415

Preprint. Discussion started: 3 December 2021

(c) Author(s) 2021. CC BY 4.0 License.

(c) (i)

Occurrence, Abundance and Biomass. 1979-2009. TINRO-Center, Vladivostok. (In Russian).

Shuntov, V.P., Bocharov, L.N., ed. 2014a. Benthic Macrofauna of the Peter the Great Bay (Japan/East Sea): Tables of Occurrence, Abundance and Biomass. 1978-2009. TINRO-Center, Vladivostok. (In Russian).

Shuntov, V.P., Bocharov, L.N., ed. 2014b. Benthic Macrofauna of the Western Part of the Bering Sea: Tables of Occurrence, Abundance and Biomass. 1977-2010. TINRO-Center, Vladivostok. (In Russian).

Shuntov, V.P., Bocharov, L.N., ed. 2014c. Benthic Macrofauna of the Sea of Okhotsk: Tables of Occurrence, Abundance and Biomass. 1977-2010. TINRO-Center, Vladivostok. (In Russian).

Shuntov, V.P., Bocharov, L.N., ed. 2014d. Benthic Macrofauna of the Northwestern Part of the Pacific Ocean: Tables of Occurrence, Abundance and Biomass. 1977-2008. TINRO-Center, Vladivostok. (In Russian).

Shuntov, V.P., Bocharov, L.N., ed. 2014e. Benthic Macrofauna of the Northwestern Part of the Japan/East Sea: Tables of Occurrence, Abundance and Biomass. 1978-2010. TINRO-Center, Vladivostok. (In Russian).

Shuntov, V.P., Dulepova, E.P., Radchenko, V.I., Temnykh, O.S. 1993. On the beginning of large reformations in communities of plankton and nekton of the Far-Eastern Seas. In: North. Pac. Mar. Sci. Org. (PICES), Second Annual Meeting Abstracts. Seattle, pp. 35.

265 Shuntov, V.P., Dulepova, E.P., Temnykh, O.S., Volkov, A.F., Naydenko, S.V., Chuchukalo, V.I., Volvenko, I.V. 2007. State of Biological Resources in Connection with Dynamics of Macroecosystems in the Far Eastern Economic Zone of Russia. In: Dynamics of Marine Ecosystems and Contemporary Issues in Conservation of Biological Potential of Russian Seas. Dalnauka, Vladivostok, pp. 75-176. (In Russian).

Shuntov, V.P., Radchenko, V.I., Dulepova, E.P., Temnykh, O.S. 1997. Biological Resources of Economic Zone: The Structure of Pelagic and Benthic Communities, Contemporary Status, and Trends of Long Dynamics. Izvestiya TINRO, 122, 3-15. (In Russian).

Shuntov, V.P., Temnykh, O.S. 2008. Pacific salmon in marine and ocean ecosystems. V. 1. TINRO-Center, Vladivostok. (In Russian).

Shuntov, V.P., Temnykh, O.S. 2011. Modern restructuring in marine ecosystems in Association with climatic changes: the priority of global or regional factors? In: Bulletin $N 6$ implementation of "Concept of the Far Eastern basin program of Pacific salmon study". TINRO-Center, Vladivostok, 49-64. (In Russian).

Shuntov, V.P., Temnykh, O.S. 2013. Illusions and Realities of Ecosystem Approach to Study and Management of Marine and Oceanic Biological Resources. Russian Journal of Marine Biology, 39, 455-473.

Shuntov, V.P., Volvenko, I.V. 2017. Supplements to quantitative assessments of zooplankton in the Far Eastern Seas and adjacent waters of the North Pacific. Izvestiya TINRO, 191, P. 130-146. https://doi.org/10.26428/1606-9919-2017191-130-146 (in Russian).

Timonin, A.G. 1983. Closing plankton nets for vertical mesoplankton catches. In: Modern methods for quantifying the distribution of marine plankton. Nauka, Moscow, 158-173. (In Russian).

Volkov, A.F. 1984. Recommendations on Express Processing of Net Plankton in the Sea. TINRO, Vladivostok. (In 
https://doi.org/10.5194/essd-2021-415

Preprint. Discussion started: 3 December 2021

(c) Author(s) 2021. CC BY 4.0 License.

(c) (i)

Russian).

Volkov, A.F. 1996a. Concerning the Technique of Plankton Sampling. Izvestiya TINRO, 119, 306-311. (In Russian).

Volkov, A.F. 1996b. Zooplankton in the Epipelagic of Far Eastern Seas: Composition of Communities, Annual Dynamics and Significance for Foraging of Nekton. Doctoral (Biol.) Dissertation thesis. DVGU, Vladivostok. (In Russian).

Volkov, A.F. 2008a. Technique of collecting and processing the samples of plankton and the samples on nekton feeding (step-by-step instructions). Izvestiya TINRO, 154, 405-416. (In Russian).

Volkov, A.F. 2008b. Quantitative parameters of zooplankton communities in the Okhotsk and Bering Seas and North-east Pacific (biomass, composition, dynamics). Izvestiya TINRO, 152, 255-270. (In Russian).

Volkov, A.F. 2012. Results of the studies on zooplankton in the Bering Sea under NPAFC program (expedition BASIS). Part 2. Western areas. Izvestiya TINRO, 170, 151-171. (In Russian).

Volkov, A.F. 2014. State of forage base for pacific salmons in the Bering Sea in 2003-2012 (by results of surveys of the international expeditions BASIS-1 and 2). Izvestiya TINRO, 179, 250-271. (In Russian).

Volkov, A.F. 2015. Integral values of biomass and stock of zooplankton in the epipelagic layer of the area 71 in the North Pacific, including the Bering and Okhotsk Seas, and patterns of distribution for mass species. Izvestiya TINRO, 180, 140-160. (In Russian).

300 Volkov, A.F. 2016. Elementary trophic ecology of pacific salmons in the Bering Sea. Species and regional differences. Provision with food in different environments. Izvestiya TINRO, 187, 162-186. (In Russian).

Volkov, A.F., Volvenko, I.V. 2016a. Net Zooplankton of the Western Part of the Bering Sea: Occurrence, Abundance, and Biomass. 1986-2013. TINRO-Center, Vladivostok. https://www.researchgate.net/publication/329139755_Net_zooplankton_of_the_western_part_of the_Bering_Sea_o ccurrence_abundance_and biomass_1986-2013 (In Russian).

Volkov, A.F., Volvenko, I.V. 2016b. Net Zooplankton of the Okhotsk Sea: Occurrence, Abundance, and Biomass. 19842013. TINRO-Center, Vladivostok.

https://www.researchgate.net/publication/329118214_Net_zooplankton_of_the_Okhotsk_Sea_occurrence_abundan ce_and_biomass_1984-2013 (In Russian).

310 Volkov, A.F., Volvenko, I.V. 2016c. Net Zooplankton of the Northwestern Pacific: Occurrence, Abundance, and Biomass. 1985-2013. TINRO-Center, Vladivostok. https://www.researchgate.net/publication/329162877_Net_zooplankton_of_the_northwestern_Pacific_occurrence_a bundance_and_biomass_1985-2013 (In Russian).

Volkov, A.F., Kuznetsova, N.A., Farley, E.V., Murphy, J.M. 2009. Structure and distribution of zooplankton and a feeding of pacific salmons in the eastern Bering Sea in the fall of 2003-2008 (results of survey under BASIS program). Izvestiya TINRO, 158, 275-292. (In Russian).

Volvenko, I.V. 2003a. Data Base and GIS Technologies in Studying Nekton of the Northwest Pacific: The First Results and Perspectives. NPAFC Doc. 730. 
https://doi.org/10.5194/essd-2021-415

Preprint. Discussion started: 3 December 2021

(c) Author(s) 2021. CC BY 4.0 License.

(c) (i)

Volvenko, I.V. 2003b. GIS and Atlas of Salmons spatial-temporal distribution in the Okhotsk Sea. NPAFC Doc. 729.

Volvenko, I.V. 2003c. New GIS for spatial-temporal dynamics analysis of Okhotsk Sea nekton. In: Abstracts of PICES 12th Annual Meeting. Seoul, pp. 111-112.

Volvenko, I.V. 2003d. Morphometric characteristic of standard biostatistical regions for the biocenological researches of Russian fishing zone on Far East. Izvestiya TINRO, 32, 27-42. (In Russian).

Volvenko, I.V. 2004a. GIS and Atlas of Salmons spatial-temporal distribution in the northwestern part of Japan (East) Sea. NPAFC Doc. 812.

Volvenko, I.V., 2004b. GIS for Spatial-Temporal Dynamics Analysis of the Okhotsk Sea Nekton. Izvestiya TINRO, 137, 144-176. (In Russian).

Volvenko, I.V. 2004c. Analysis of the rate of alternativeness in abundance dynamics of different species in the case of absent continuous long time series data: an example of the Okhotsk Sea nekton. Izvestiya TINRO, 139, 78-90. (In Russian).

Volvenko, I.V. 2005a. GIS and Atlas of Salmons Spatial-Temporal Distribution in the Northwestern Part of the Pacific Ocean. NPAFC Doc. 879.

Volvenko, I.V. 2005b. GIS and Atlas of Salmons spatial-temporal distribution in the western part of the Bering Sea. NPAFC Doc. 880.

Volvenko, I.V. 2007. New GIS of the Pelagic Macrofauna Integrative Characteristics for the North-West Pacific. Izvestiya TINRO, 149, 3-20. (In Russian).

Volvenko, I.V. 2014a. Regional Data Center (RDC) of FSUE “TINRO-Center”: Its Principal Activities and Role in the Prediction of Fisheries Resource State. Izvestiya TINRO, 176, 3-15. (In Russian).

Volvenko, I.V. 2014b. The New Large Database of the Russian Bottom Trawl Surveys in the Far Eastern Seas and the North Pacific Ocean in 1977-2010. International Journal of Environmental Monitoring and Analysis, 2, 302-312.

Volvenko, I.V. 2015a. Dataware Support of Comprehensive Studies of Northwestern Pacific Aquatic Biological Resources. Part 1. Concept, Background, Beginning of Implementation. Trudy VNIRO, 156, 38-66. (In Russian).

Volvenko, I.V. 2015b. Dataware Support of Comprehensive Studies of Northwestern Pacific Aquatic Biological Resources. Part 2. Databases, Knowledge Bases, Automated Workplaces. Trudy VNIRO, 157, 71-99. (In Russian).

Volvenko, I.V. 2015c. Dataware Support of Comprehensive Studies of Northwestern Pacific Aquatic Biological Resources. Part 3. GIS, Atlases, Reference Books, Further Prospects of the Concept. Trudy VNIRO, 157, 100-126. (In Russian).

Volvenko, I.V. 2015d. The role of the Regional Data Center (RDC) of the Pacific Research Fisheries Center (TINROCenter) in North Pacific ecosystem and fisheries research. International Journal of Engineering Research \& Science, 1, 47-54.

Volvenko, I.V. 2016. The concept of information support for bioresource and ecosystem research in the North-West Pacific: Theory and practical implementation. Natural Resources, 7, 40-50. 
https://doi.org/10.5194/essd-2021-415

Preprint. Discussion started: 3 December 2021

(c) Author(s) 2021. CC BY 4.0 License.

(c) (1)

Volvenko, I.V. 2017. A comparative study of the Far Eastern Seas and the Northern Pacific Ocean based on integral parameters of net zooplankton in the Epipelagic Layer. Russian Journal of Marine Biology, 43(7), 568-582. DOI: 10.1134/S1063074017070069

Volvenko, I.V. 2019. New net zooplankton geographical information system in the Far East seas and adjacent waters of the Pacific Ocean. Global Ecology and Biogeography, 28, 1735-1748. https://doi.org/10.1111/geb.13002

Volvenko, I.V. 2020. Geographical zonation in the distribution of the integral characteristics of net zooplankton in Far Eastern seas and in the North Pacific. Science of the Total Environment. 715, 136961. https://doi.org/10.1016/j.scitotenv.2020.136961

Volvenko, I.V. 2021a. Digitized, corrected and translated data on net zooplankton of the Far East seas and adjacent Pacific Ocean waters from five rare reference books published in Russian in limited editions. PANGAEA. https://doi.pangaea.de/10.1594/PANGAEA.937751

Volvenko, I.V. 2021b. GIS of standard Regions for averaging data from plankton and trawl surveys with their morphometric characteristics. PANGAEA. https://doi.pangaea.de/10.1594/PANGAEA.937752

Volvenko, I.V., Kulik, V.V. 2011. Updated and Extended Database of the Pelagic Trawl Surveys in the Far Eastern Seas and North Pacific Ocean in 1979-2009. Russian Journal of Marine Biology, 37, 513-532.

Volvenko, I.V., Kulik, V.V., Shuntov, V.P. 2014a. Database "Pelagic trawl macrofauna of the North Pacific 1979-2009". Copyright certificate No. 2014620536, Russia. (In Russian).

Volvenko, I.V., Kulik, V.V., Shuntov, V.P., Nadtochiy, V.A., Il'insky, V.N., Tuponogov, V.N., Savin, A.B., Gerasimov, N.N., Shevtsov, G.A. 2014b. Database "Bottom trawl macrofauna of the North Pacific 1977-2010”. Copyright certificate No. 2014620535, Russia. (In Russian).

Volvenko, I.V., Kulyk, V.V., Shuntov, V.P., Ivanov, O.A., Starovoytov, A.N., Shevtsov, G.A., Chuchukalo, V.I. 2012. Database "Pelagic trawl macrofauna of the North Pacific 1979-2005". Copyright certificate No. 2012620963, Russia. (In Russian).

Volvenko, I.V., Volkov, A.F., Dolganova, N.T. 2016. Database "Net zooplankton of the North Pacific 1984-2013". Copyright certificate No. 2016620026, Russia. (In Russian). 

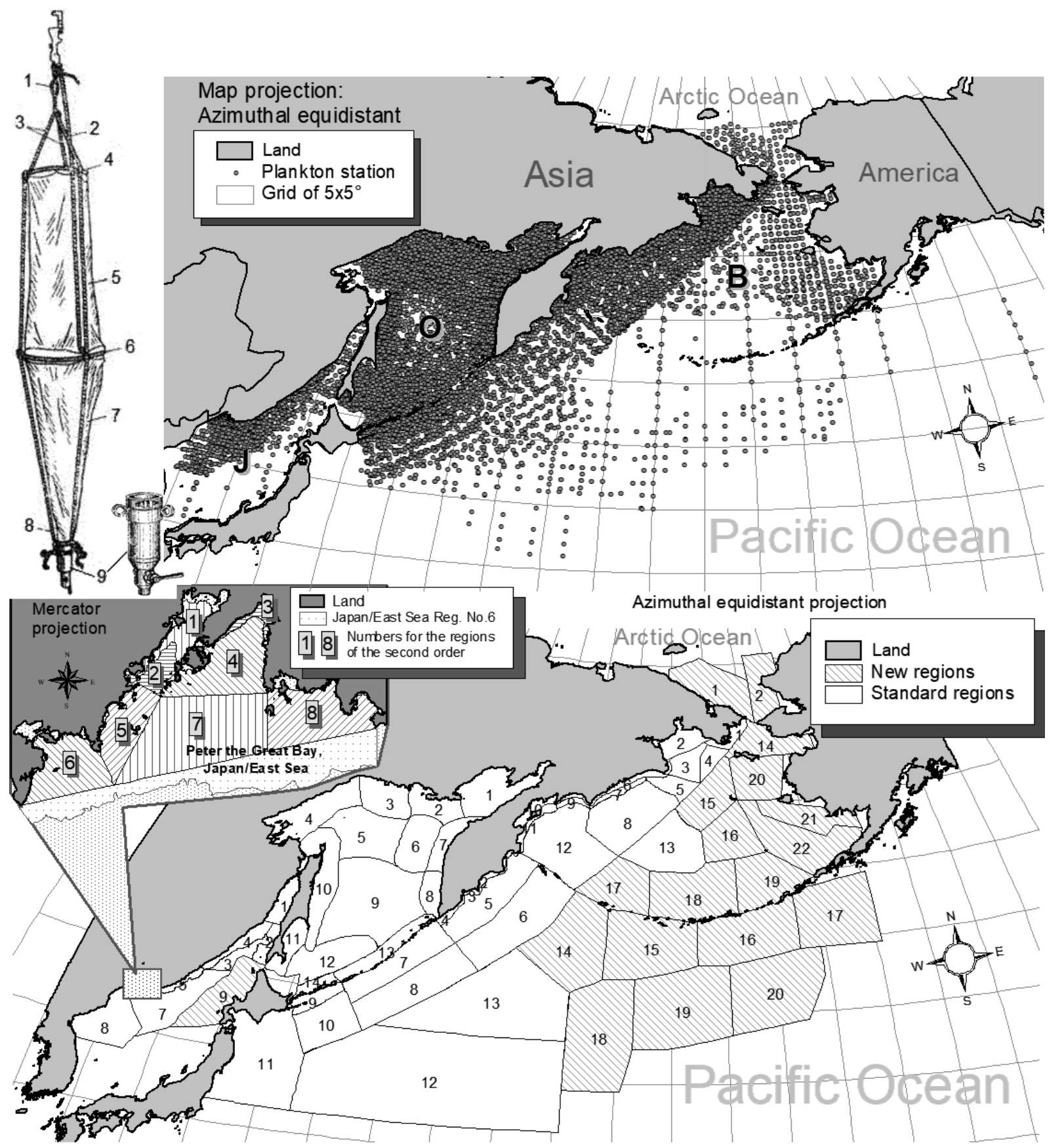

Figure 1: The upper left corner shows Large Juday plankton net: 1 - cord loop, 2 - cord that connects the net to the closing device, 3 - cords on the upper ring, 4 - upper ring, 5 - cloth cone, 6 - lower ring, 7 - silk net, 8 - cord that holds the tub, 9 - tub. The top map shows spatial distribution across the surveyed waters of 25,512 plankton measurement stations (235 surveys), from which the data obtained, has been entered into the database. Abbreviations: B - Bering Sea, O - Sea of Okhotsk, J - Sea of Japan (East Sea). The bottom map shows standard regions in which averaging of biostatistical information in the waters of permanent (light) and periodic (shaded) monitoring is performed. In the middle left tab - secondary regions, which the 6th region of the Sea of Japan is divided into. 